11 | 2007

Varia

\title{
Calendrier des activités (juillet 2007 - juin 2008)
}

\section{(2) OpenEdition}

1 Journals

Édition électronique

URL : https://journals.openedition.org/cem/1199

DOI : $10.4000 /$ cem. 1199

ISSN : 1954-3093

Éditeur

Centre d'études médiévales Saint-Germain d'Auxerre

Édition imprimée

Date de publication : 15 août 2007

ISSN : 1623-5770

Référence électronique

"Calendrier des activités (juillet 2007 - juin 2008) », Bulletin du centre d'études médiévales d'Auxerre I

BUCEMA [En ligne], 11 | 2007, mis en ligne le 26 avril 2010, consulté le 22 septembre 2022. URL :

http://journals.openedition.org/cem/1199; DOI : https://doi.org/10.4000/cem.1199

Ce document a été généré automatiquement le 22 septembre 2022.

\section{(c) (i) (2) (2)}

Creative Commons - Attribution - Pas d'Utilisation Commerciale - Partage dans les Mêmes Conditions 4.0 International - CC BY-NC-SA 4.0

https://creativecommons.org/licenses/by-nc-sa/4.0/ 


\section{Calendrier des activités (juillet 2007 - juin 2008)}

\begin{tabular}{|l|l|}
\hline 2-20 juillet & Auxerre, Stage : l'archéologie du bâti religieux, la cathédrale Saint-Étienne. \\
\hline $\begin{array}{l}\text { 27-29 } \\
\text { septembre }\end{array}$ & $\begin{array}{l}\text { Auxerre, La cathédrale Saint-Étienne d'Auxerre : résultats récents des recherches } \\
\text { pluridisciplinaires et internationales, Christian SAPIN }\end{array}$ \\
\hline $\begin{array}{l}\text { 4-6 octobre } \\
\text { Besançon, "Nouveaux servages" et société en Europe, XIIIe-XIXe siècles, Nicolas } \\
\text { CARRIER } \\
\text { novembre }\end{array}$ & $\begin{array}{l}\text { Auxerre, " Les usages sociaux de la Bible ", numéro de la revue Médiévales, } \\
\text { Dominique IOGNA-PRAT }\end{array}$ \\
\hline
\end{tabular}

\begin{tabular}{|l|l|}
\hline $\begin{array}{l}25 \\
\text { janvier }\end{array}$ & $\begin{array}{l}\text { Dijon, Chartae Burgundiae Medii Aevi. La diplomatique en Bourgogne (II). Journée d'étude, } \\
\text { Eliana MAGNANI, Marie-José GASSE-GRANDJEAN }\end{array}$ \\
\hline \hline avril & Stage d'archéologie du bâti (dates et lieu à préciser) \\
\hline $\begin{array}{l}25-26 \\
\text { avril }\end{array}$ & $\begin{array}{l}\text { Luxeuil, Présentation et mise en valeur des sites archéologiques religieux en milieu } \\
\text { urbain, Sébastien BULLY, Christian SAPIN }\end{array}$ \\
\hline $\begin{array}{l}11-13 \\
\text { juin }\end{array}$ & Lyon-Pérouges, "La trahison au Moyen Âge", Maïté BILLORÉ \\
\hline
\end{tabular}


19-20 Auxerre, Images et passages à l'époque médiévale, Dominique Donadieu-Rigaut juin

3 Contact : cnrs.cem@wanadoo.fr 